\title{
Entrevista com a reitora Roselane Neckel
}

\section{Que papel a extensão universitária cumpre na produção e difusão do conhecimento e nos processos de formação profissional?}

Resposta: As atividades de extensão são muito importantes para aproximar a UFSC de diversos setores de nossa sociedade. Elas ajudam, a um só tempo, a formar bons profissionais e a colocá-los em contato direto com públicos distintos, com problemas reais, instigando-os a encontrar soluções a partir do conhecimento gerado em nossa universidade.

2. No que a extensão contribui com os demais processos internos e externos à universidade e no cotidiano da sociedade?

Resposta: A contribuição é contínua. Há muitos exemplos que poderíamos citar, a partir de projetos desenvolvidos aqui mesmo na UFSC. O Núcleo de Estudos da Terceira Idade (NETI), que acaba de completar 30 anos e que desenvolve um belíssimo trabalho, com relevância social indiscutível, é um deles. Há muitos outros projetos, ligados a temas como preservação do meio ambiente, saúde coletiva, educação no campo, tecnologia e inovação. A maior parte deles tem algum impacto tanto na UFSC quanto na sociedade de um modo geral. É incalculável o impacto causado por ações que visam levar orientação sobre saúde bucal a jovens de regiões do nosso entorno, por exemplo, assim como é inegável que ações no campo mudam - e muito - a vida das pessoas, promovendo a interação com a comunidade local, reconhecendo os desafios e propondo, em parceria, caminhos para superá-los.

\section{Foi a consciência desta importância que a fez criar a Pró-Reitoria de Extensão para a gestão 2012-2016?}

Resposta: Durante a elaboração de nosso plano de trabalho e no diagnóstico realizado pela nossa equipe à época da transição, ficou bem claro que era necessário criar a PROEX, pois avaliamos que pesquisa e extensão deveriam ter a mesma importância institucional. Nesse sentido, tenho convicção de que foi uma decisão acertada.

\section{A Revista Extensio tem por finalidade dar visibilidade ao papel extensionista incrementado na UFSC, assim como às experiências extensionistas desenvolvidas em todo o país e em outras nações, colaborando, portanto, para a interação com outros gru- pos sociais e para a internacionalização da UFSC. Como a senhora acha que essa finali- dade da Revista Extensio poderia cooperar especificamente para consolidar o tripé ensi- no-pesquisa-extensão?}

Resposta: Uma publicação como a Extensio é muito interessante, sobretudo porque promove a visibilidade das ações realizadas de um modo diferente dos tradicionais. Por ter um viés crítico e acadêmico, ela proporciona um espaço para que o público conheça melhor o que tem sido realizado na universidade e como essas atividades estão articuladas em torno deste ideal possível que é unir ensino, pesquisa e extensão na construção do conhecimento. Por isso, uma das nossas prioridades é fortalecer o periódico e dar condições para que sua produção seja contínua. 